\title{
Catch variation of a set net fishing ground in the coastal waters off Neungpo, Goeje Island
}

\author{
Byung-Yul CHA* \\ Aquaculture and Resource Enhancement Division, East Sea Fisheries Research Institute, \\ NFRDI, Gangneung 210-861, Korea
}

The fisheries resources by a set net in the coastal waters off Neungpo, Goeje Island from 2003 to 2004 were studied to determine species composition and catch variation. The main fishing period by a set net were from April to December in 2003 and from May to December in 2004. A total weight of 48 species caught through the survey period was 540,688.0kg. Most of them were 44 species of fishes and a few were 4 species of cephalopods. Dominant species was Trachurus japonicus accounting to 57.5\% in total catch. Subdominant species were Trichiurus lepturus(12.9\%), Engraulis japonicus(10.6\%), Scomber japonicus(6.9\%), Clupea pallasii(4.5\%), Todarodes pacificus(2.8\%) and Parapristipoma trilineaturm (1.3\%). The remnant species showed a low catch, indicating the catch had less than $1 \%$ in total, respectively. T. japonicus and $\mathrm{T}$. lepturus were caught throughout the survey period, but C. pallasii, Gadus macro-cephalus, Oncorhynchus keta in low temperature season and Thunnus obesus in high temperature season. The fishing ground temperature was $11.7-24.0^{\circ} \mathrm{C}$ in range and the catch by a set net was higher in autumn than in spring and in summer with the variation of fishing ground temperature. The annual catch by a set net was much higher in 2004 than in 2003 due to high temperature $\left(>17^{\circ} \mathrm{C}\right.$ ) and the recruitment of $T$. japonicus from offshore seas. Therefore we concluded that the catch of Neungpo fishing ground by a set net was highly related to the variation of $T$. japonicus catch with fishing ground temperature.

Key words : Goeje Island, Neungpo, Set net, Trachurus japonicus, Catch variation

*Corresponding author: bycha@nfrdi.go.kr, Tel: 82-33-660-8526, Fax: 82-33-661-8514 


\section{서 론}

우리나라 연안의 어류는 단일 종에 의한 구성 보다는 여러 종에 의한 복합적 구성을 지니며, 특히 소수 종에 의한 우점도가 높다. 또한, 해역 과 시기에 따라 서식하는 종과 우점종이 다르며, 분포량도 많은 차이를 보이고 있다(Cha et al., 2007). 그러나, 연안의 표영계는 상호간의 서식 공간이 열려있기 때문에 먼 거리라 할지라도이 동성이 강한 어종들에 의해 어류의 조성 및 분포 에 영항을 미칠 수 있다. 따라서, 표영계에서는 한 해역에 있어서 어류의 증가 및 감소가 다른 해역의 증가 및 감소에 도 영향을 미칠 수 있으며 (Cha et al., 2001, 2004), 최 근에 는 자연 상태에 의 한 증가와 감소보 다는 사람에 의 한 과도한 어 획 과 환경조건의 악화에 의해 여러 해역이 동시적 으로 영항을 받는 경 우가 많다. 그러므로 표영계 의 어류에 대한 동태 및 생태를 올바로 이해하기 위해서는 일부해역에서 뿐만 아니라 주변해역 을 포함한 여러 해역을 종합한 개체군 단위별로 조사에 접근할 필 요가 있다.

본 연구는 이러한 연구의 일 환으로 거제도 동 부의 능포 연안에서 정치망 어업에 의한어획물 조사를 실시한 것이다. 정치망 어업은 바다의 해 수면 가까이에서 주로 조업이 이루어지기 때문 에 저 층부근에서 조업이 이루어 지는 통 발, 자망, 저인 망 둥의 어구들에 비하여 표영 성 어종 (pelagic fish) 들이 많이 어획되 고 있는 실 정이다.

지금까지 우리 나라에서 수행 된 연안 정치 망에 의한 어획물 연구를 살펴 보면, 먼저 남해 안에서 는 Kim et al.(1988)의 여수 연 안 정치망 어장의 해황과 어 황에 관한 연 구, Kim et al.(1989)의 여 수해만의 어장학적 특성, Kim(1993)에 의한 여 수 연안 정 치망 어장의 환경요인과 어 황변 동에 관한 연구, Kim and $\operatorname{Rho}(1995,1996)$ 의 여수 연 안 정치망 어장의 환경요인과 어 황변 동에 관한 연구, Kim et al.(2003)의 여수 연안 정치망 어획 물의 종조성과 계절변동 둥이 있다. 다음으로 동 해안에서는 Hong and Lee(1995) 에 의 한 경 북 연
안 정치망 어획량 변동에 관한 연구, Han et al.(2001)의 울산 연안 정치망에 어획된 어류의 종조성 및 앙적변동 등이 있다. 또한 제주도 주 변의 경우, Go and Shin(1988)의 제주도 북촌 연 안의 유영생물의 종 조성과 다양도, Go and Shin(1990)의 제주도 남부 화순 연안 수산자원 유영생물의 종 조성과 다양도, Kim et al.(1999) 에 의한제주도 한림 연안 정치망 어장의 환경특 성과 어획량 변동에 관한 연구 그리고 Cha et al.(2001)에 의한 제주도 연안 정치망 어획량 변 동과 어기, Cha et al.(2004)의 제주도 함덕 연안 의 정치망 어획량 변동, Cha et al.(2008)의 제주 도 귀덕 연안 정치망 어획물의 조성 및 변동 등 을 들 수가 있다. 이들 연구에서는 특히 전갱이 가 많이 어획되는 어 종 중의 하나이 었으며, 조사 지역인 남해안과 제주도 주변 그리고 동해안에 서 고루 어획되는 것으로 보아 우리나라에서는 분포범위가 넓고 다량 분포하고 있는 어종임을 알 수가 있다. 그러므로 정치망 어황 연구를 통 하여 전갱이 어군의 생태를 이해할 수 있는 기초 자료를 제 공받을 수 있으며, 전 갱이 어군의 생태 를 이해한다면 우리나라 연 안 정치망 어업의 어 황 변동요인도 어느정도 이해할 수 있을 것으로 생각된 다.

본 연구에서는 많은 회유성 어종들이 지나가 는 길목이며, 전 갱이 어군이 다량 유입되 고 있는 거제도 동부 연안의 능포 정치망 어장에서 어획 되는 어획물의 어획량 변 동 등에 대하여 알아보 고자 하였다.

\section{재료 및 방법}

거제도 능포 연안에서 정치망에 의한 어획물 조사를 하였다(Fig. 1). 본 해역은 난류수와 한류 수의 영향을 계절에 따라 교대로 받고 수심이 깊 은 동해와 대한해협으로 연결되며, 계절적으로 다양한 그룹의 생 물들이 내 유하여 오는 수산해 양학적 으로 중요한 곳이다.

조사기간은 2003년부터 2004 년까지 2년 동안 


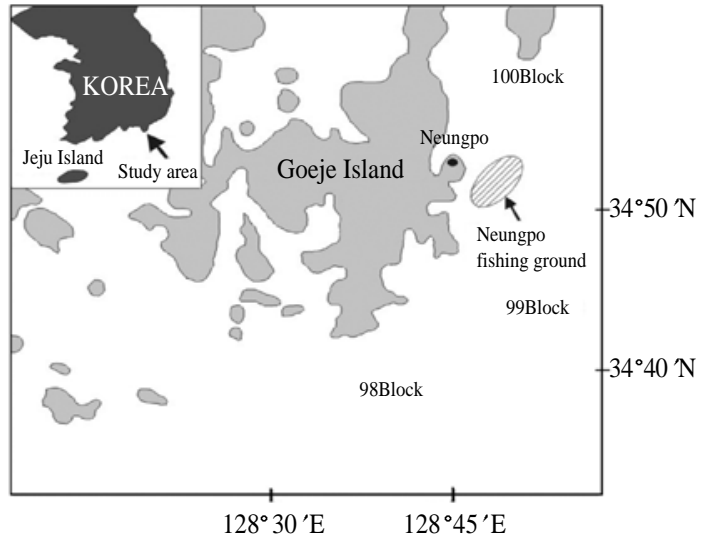

Fig. 1. Sampling site for fisheries resources study by a set net in the coastal waters off Neungpo, Goeje Island from 2003 to 2004 (The block numbers within map indicate the fishing ground range by purse seine fishery).

어업인에 의해 실제 조업이 행해지는 기간이었 다. 정치 망 어장의 수심 은 $30 \mathrm{~m}$ 미만이다. 사용된 정치망은 낙망(이 중편 낙망) 으로 어 구의 규격은 혓통(Fish court) 의 길이 $132 \mathrm{~m}$, 망목 $121 \mathrm{~mm}$ 이며 그리 고 비탈 그물(Inclined passage) 길이 는 $60 \mathrm{~m}$, 망 목 $76 \mathrm{~mm}$ 이다. 여기서 어류를 어망으로 유도하는 길그물(Leader)의 길이는 $585 \mathrm{~m}$ 이다. 어구가 설치 된 수심은 $27 \mathrm{~m}$ 이며, 어획된 어획물은 종별로 구 분한 뒤, 어종별 어획 량과 어획비율을 구하였다.

정치망에 의한 능포 연 안의 어획물 조성 및 어 획량 변동을 분석하기 위하여 수산자원의 분포 와 이 동에 가장영 항을 미치는 수온에 대하여 조 사를 실시하였다. 이 때, 수온의 측정 장소는 정 치망 어 구가 설치되어 있는 표층의 표면하 $10 \mathrm{~m}$ 이며, CTD (SBE 19 plus V2) 를 이용하여 $0.1^{\circ} \mathrm{C}$ 단위까지 매월 중순경 조금 전후에 측정하였다.

한편, 정치망 어획량의 변동요인을 이해하기 위하여 거제도 능포의 근해어장에서 어획되는 근해어종의 어획량도 함께 조사하였다. 근해어 장은 능포 연 안에 인 접한 98 해구, 99 해 구 그리고 100 해 구의 3 곳이며, 이곳에 서 대형선 망어업 (Large purse seine fishery)에 의해 어획되는 해 구 별 어획량(NFRDI, 2003 -2004)으로 구하였 다.

\section{결 과}

정치망 어장의 수온변화

2003년 과 2004년 거제도 능포 연안 정치망 어 장의 월 수온변동을 Fig. 2 에 나타내 었다. 2003 년 1 월 부터 3 월 까지 $11.7-12.1^{\circ} \mathrm{C}$ 의 수온범 위를 기록하였고, 4 월 이 후에 는 점차 상승하여 8 월 과 9 월 에는 수온이 약 $24^{\circ} \mathrm{C}$ 를 기록하였다. 10 월 에 는 다시 하강하여 $20^{\circ} \mathrm{C}$ 미 만을 기록하였고, 12 월 에는 약 $15^{\circ} \mathrm{C}$ 까지 하강하였다.

2004 년 에는 1 월 부터 5 월 까지 $12.2-14.8^{\circ} \mathrm{C}$ 의 수온범 위를 그리고 6 월 에는 $16^{\circ} \mathrm{C}$ 이상의 수온 을 기록하였으며, 8 월 과 9 월 그리고 10 월 에 는 $20^{\circ} \mathrm{C}$ 이상으로 수온이 상승하였다.

2003년 과 2004년의 월 어장수온 변동에는 뚜 렷한 차이는 없었으나, 2004 년 의 경 우 2003 년에 비하여 1 월 부터 4 월 까지 는 $0.5-2^{\circ} \mathrm{C}$ 정도 높은 수온을, 6 월 부터 8 월 까지는 반대로 $2^{\circ} \mathrm{C}$ 정 도 닞 은 수온을 기록하였다. 연 평균수온은 2003 년이 $18.3^{\circ} \mathrm{C}, 2004$ 년 이 $18.0^{\circ} \mathrm{C}$ 로 2003 년 이 2004 년에 비하여 $0.3^{\circ} \mathrm{C}$ 높았다.

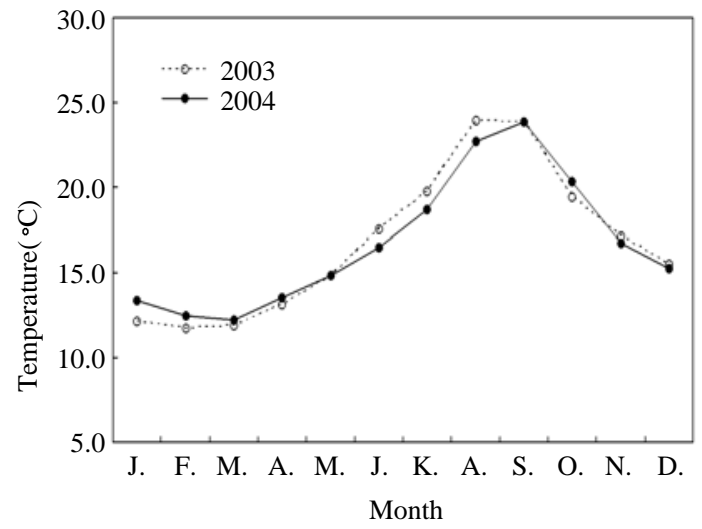

Fig. 2. Monthly variation of temperature in the coastal waters off Neungpo, Goeje Island from 2003 to 2004.

\section{정치망의 어획물 조성}

2003 년부터 2004 년까지 2 개년 동안 능포 어장 에서 어획된 어획 물의 총 어획 량은 $540,688.0 \mathrm{~kg}$ 그리 고 어획 된 어종은 충 48 어종이었 다(Table 1). 
Table 1. Species composition and abundance of fisheries resources caught by a set net in the coastal waters off Neungpo, Goeje Island from 2003 to 2004

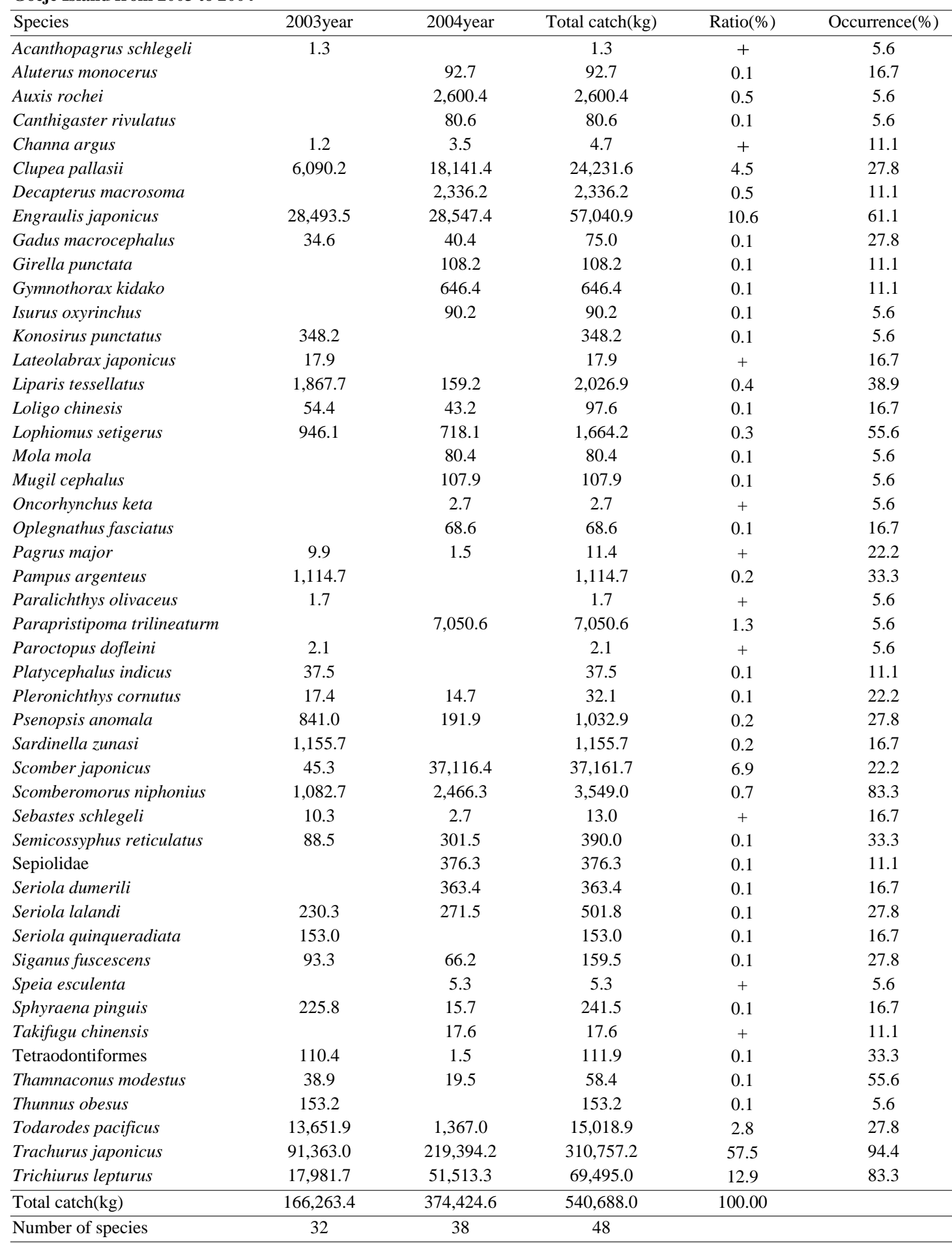

+ ; less than 0.1 
2003 년의 어획량은 $166,263.4 \mathrm{~kg}$, 어 종은 32 어 종 이며, 2004년의 어획량은 $374,424.6 \mathrm{~kg}$ 그리고 어 종은 38 어종이며, 어획량과 어 종수에서 2004 년 이 2003년에 비하여 많았다. 어종별로 보면, 전 갱이(Trachurus japonicus) 가 $310,757.2 \mathrm{~kg}$ 로 전 체 의 $57.5 \%$ 를 차지하여 가장 많이 어획되었다. 다 음으로 갈치(Trichiurus lepturus) 가 $69,495.0 \mathrm{~kg}$ (12.9\%)으로 많았다. 그 외 멸치(Engraulis japonicus) 57,040.9kg(10.6\%), 고 등어(Scomber japonicus) $37,161.7 \mathrm{~kg}(6.9 \%)$, 청 어 (Clupea pallasii) 24,231.6kg(4.5\%), 살오징 어(Todarodes pacificus) $15,018.9 \mathrm{~kg}(2.8 \%)$ 그리 고 벤자리 (Parapristipoma trilineaturm) 가 7,050.6kg(1.3\%) 이었으며, 그 외 어종들은 전체 어획량에서 각 $1 \%$ 미 만을 차지하였다.

\section{정치망의 어획량 변동}

거제도 능포 정치망 어장은 2003년 4월 부터 주 조업이 시작되어 5 월에 $15,000 \mathrm{~kg}$ 이상 그리 고 6 월 에는 $20,000 \mathrm{~kg}$ 으로 점차 증가하였다(Fig. 3). 7 월 과 8 월 에는 각각 $26,000 \mathrm{~kg}, 28,000 \mathrm{~kg}$ 정 도 의 어획량을 나타내었으나, 9 월 과 10 월 에는 태 풍(매미)에 의한 어 망파손으로 조입이 일시적으 로 이루어지지 않아 다시 $15,000 \mathrm{~kg}$ 미 만으로 닞 아졌다. 그러나, 12 월 에는 $37,000 \mathrm{~kg}$ 이상으로 월 어획량이 재차 증가하였으며, 이 시기의 주어획 종은 멸치와 전 갱이, 청어 등이었다.

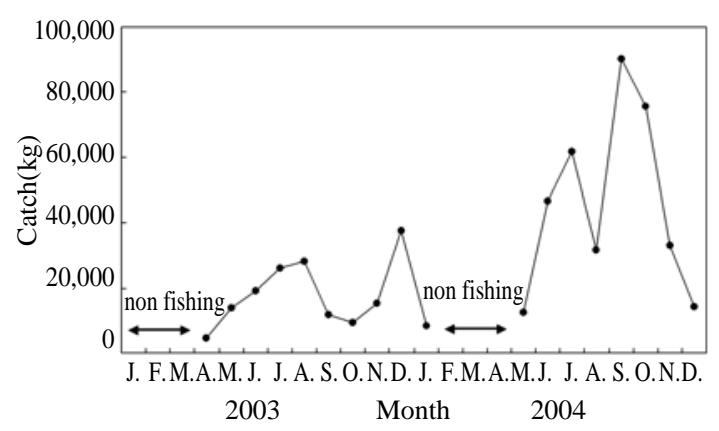

Fig. 3. Monthly catch by a set net in the coastal waters off Neungpo, Goeje Island from 2003 to 2004.
2004 년 에는 1 월 에 약간의 어획량 $(10,000 \mathrm{~kg}$ 미 만)을 나타내었으나, 2 월 부터 4월까지 휴어기 로 인 한 어획량이 없었다. 그러나, 5월 부터 조업이 재 개되 어 6 월 에는 약 $50,000 \mathrm{~kg}$ 그리고 7 월 에는 $60,000 \mathrm{~kg}$ 이상의 어 획량을 나타내 었다. 9 월 에는 더욱 상승하여 약 $90,000 \mathrm{~kg}$ 을 나타내 었으나, 10 월 이후에 는 점차 감소하여 12 월 에는 $15,000 \mathrm{~kg}$ 정 도로 낮아졌 다. 따라서 2003년 에 비하여 2004 년의 정치망 어획량은 변동 폭도 컸고, 월 어획 량도 많았다.

주 어종 전갱이의 어획량 변동

주 어종인 전 갱이의 어 획량 변 동을 Fig. 4 에 나 타내었다. 2003 년 의 경우, 전 갱이는 5 월에 어획 되 기 시 작하여 6 월 에 $13,000 \mathrm{~kg}$ 이상 그리고 7 월 에 $20,000 \mathrm{~kg}$ 이상의 어획량을 나타내 었다. 8 월 이후 점차 감소하여 12 월 에는 다시 $10,000 \mathrm{~kg}$ 미 만으로 낮아졌다. 2004년 1월 에는 어획량이 적 었으며, 5 월부터 어획이 시작되어 7 월에 약 $60,000 \mathrm{~kg}$ 그리고 9 월 에 $70,000 \mathrm{~kg}$ 이상으로 증가 하였다. 2003 넌과 2004년의 어기동안 전 갱이는 매월 어획되었으며, 어획량 변동도 전체 정치망 변 동양상과 비슷하였다.

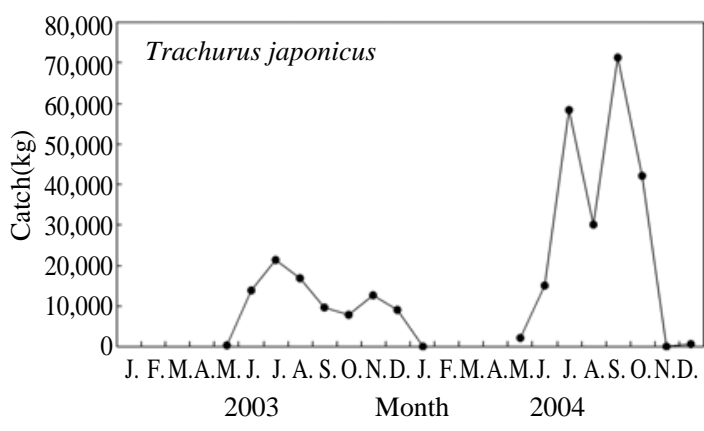

Fig. 4. Monthly variation of Trachurus japonicus catch by a set net in the coastal waters off Neungpo, Goeje Island from 2003 to 2004.

근해어장에 있어서의 전갱이 어획량 변동

2003 년부터 2004 년까지 거제도 능포 어장의 인 근해 역인 $98,99,100$ 해 구에서 대 형선 망에 의 


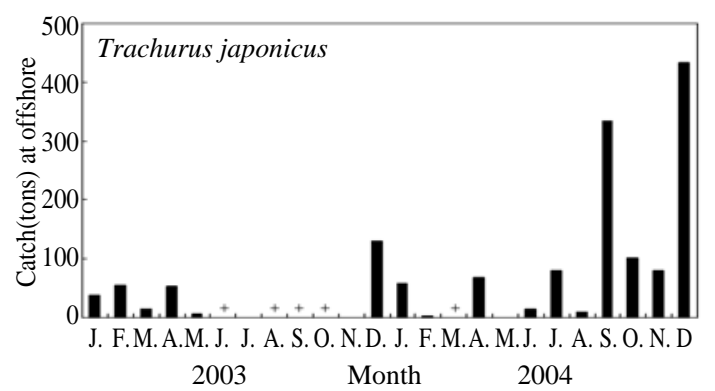

Fig. 5. Monthly catch of Trachurus japonicus caught by purse seine in offshore fishing ground (98, 99, 100 block) off Neungpo, Goeje Island from 2003 to 2004. The plus sign within figure is less than 1 ton.

해 어획된 전갱이 어획량을 Fig. 5 에 나타내었 다. 본 해구들은 정치망 어장에 가장 가까운 해 역들로 전갱이 어군들이 많이 분포하는 해역이 며, 이곳의 전갱이 어황이 시기에 따라 거제도 연 안에 많은 영항을 미치는 곳이기도하다. 어획 량을 보면, 2003 년 1 월 부터 4월까지 매월 10 톤 이 상을 나타내 었으나, 6 월 부터 10 월 까지 는 1 톤 미만으로 감소하었다. 다시 2003년 12 월에 는 130 톤 이상의 어 획량을 나타내 었고, 2004년 1 월 에는 60 톤 정 도의 어획량을 나타내 었다. 2004년 4월 이후부터 전갱이 어획량은 점차 증가하는 경향을 나타내 어 9 월 에는 300 톤 이상, 12 월 에는 400 톤 이상까지 나타내 었다.

정치망 전갱이 어획량과 전체 정치망 어획량과 의 관계

능포 정치망 어장에서 어획된 전 갱이 어획량 과 전체 정치망 어획량과의 관계를 Fig. 6 에 나 타내었다. 먼저, 2003 년 에는 월 별에 따른 전갱이 어획량과 전체 어획량 간에는 별 다른 관련성을 보이지 않았다 (상관관 계 식, $\mathrm{y}=0.8399 \mathrm{x}+$ 9943.4, 결정계수 $\left.\mathrm{r}^{2}=0.3211\right)$. 하지만, 2004 년의 경우에는 월별 전갱이 어획량과 전체 정치망 어 획 량 간에는 상관관계가 매우 높았다(상관관계 식, $\mathrm{y}=0.9559 \mathrm{x}+18298$, 결정 계수 $\left.\mathrm{r}^{2}=0.8105\right)$. 즉, 전갱이 어획량이 많으면 많을 수록 정치망 어획량 또한 크게 증가하었다. 그러므로, 월별

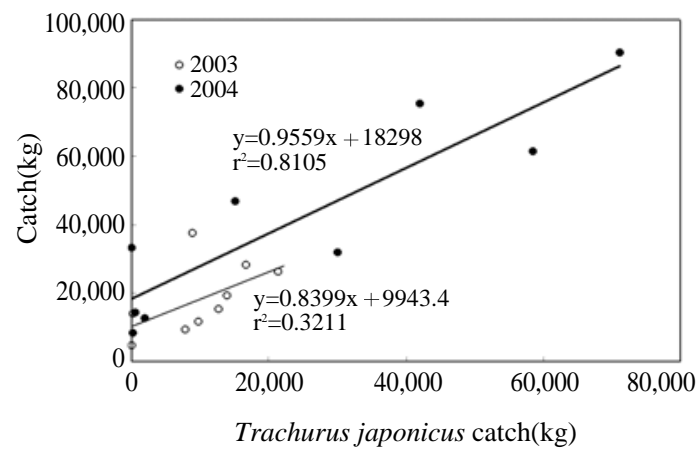

Fig. 6. Relations between monthly catch and Trachurus japonicus catch by a set net in the coastal waters off Neungpo, Goeje Island, 2003 and 2004.

정치망 전 갱이 어획량이 적었던 2003 년에 비하 여 월별 정치망 전 갱이 어획량이 많았던 2004 년 의 경우, 전갱이 어획량이 정치망 어황과 많은 관련이 있었음을 알 수 있다.

$17^{\circ} \mathrm{C}$ 기준에 의한 정치망 전갱이 어획량과 근해 전갱이 어획량과의 관계

한편, $17^{\circ} \mathrm{C}$ 어장수온을 기준으로 정치망에서 의 전갱이 어획량과 근해 전갱이 어획량과의 관 계를 Fig. 7 에 나타내었다. 정치 망 어장수온이 $17^{\circ} \mathrm{C}$ 미 만일 때는 정치망 전 갱이 어 획량과 근해 의 전갱이 어획량 간에는 별다른 관 련성을 보이 지 않았다 관계식, $\mathrm{y}=-0.0012 \mathrm{x}+2006.4$, 결 정 계수 $\left.r^{2}=0.0009\right)$. 근해 전갱이 어획량이 400 톤 이상이라 하더래도 정치망에서의 전갱이 어획 량은 1 톤 미 만으로 극히 낮았다. 그러나, 어장수 온이 $17^{\circ} \mathrm{C}$ 이상일 때 는 근해 전 갱이 어획량이 많으면 많을 수 록 정치망에서의 전 갱이 어획량 또한 크게 증가하였 다(관계식, $\mathrm{y}=0.1796 \mathrm{x}+$ 18923 , 결정계수 $\left.\mathrm{r}^{2}=0.7486\right)$. 근해 전갱이 어획 량이 10 톤 미 만에 서도 정치망의 전갱이 어획량 은 30 톤 까지 나타내 었다.

그러나, 정치망 어 장수온이 $17^{\circ} \mathrm{C}$ 이 상인 기간 중에 어획된 전갱이 어획량을 해역별, 연도별로 비고하여 보면(Table 2), 정치망에서 는 어 획량이 2003 년 82 톤 그리고 2004년이 202 톤이었다. 같 


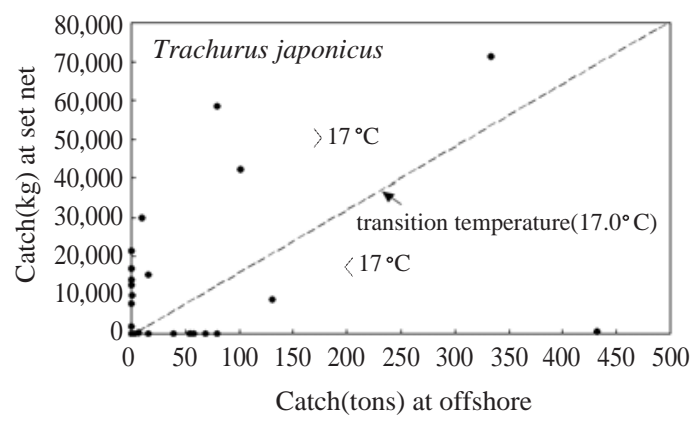

Fig. 7. Monthly catch relations between at Neungpo fishing ground and at offshore fishing ground by Trachurus japonicus from 2003 to 2004.

Table 2. Comparison of Trachurus japonicus catch during high temperature $\left(>17^{\circ} \mathrm{C}\right.$ ) period in 2003 year and 2004 year

\begin{tabular}{cccc}
\hline Item & $\begin{array}{c}\text { High } \\
\text { temperature } \\
\text { month }\end{array}$ & $\begin{array}{c}\text { T.japonicus } \\
\text { catch } \\
\text { at set net }\end{array}$ & $\begin{array}{c}\text { T.japonicus } \\
\text { catch } \\
\text { at offshore }\end{array}$ \\
\hline 2003(A) & $\begin{array}{c}\text { June-November } \\
\text { (6 months) }\end{array}$ & 82 tons & $\doteqdot 2$ tons \\
\hline 2004(B) & $\begin{array}{c}\text { July-October } \\
\text { (4 months) }\end{array}$ & 202 tons & 525 tons \\
\hline $\begin{array}{c}\text { Co-comparison } \\
\text { Index(B/A) }\end{array}$ & 0.7 & 2.5 & 262.5 \\
\hline
\end{tabular}

은 기간의 근해 $(98,99,100$ 해 구)에서 대형선 망 에 의한 전 갱이 어획량은 2003 년이 약 2 톤, 2004 년이 525 톤이었다. 따라서 정치망에서의 전갱이 어 획량은 2004 년 이 2003 년 에 비 하여 2.5 배 그리 고 근해에서의 전갱이 어획량은 2004년이 2003 년 에 비하여 260 배 이 상높았다. 고수온 $\left(17^{\circ} \mathrm{C}\right.$ 이 상) 의 기간은 2003 년 이 6 월 부터 11 월 까지 6 개 월 이 며, 2004 년 은 7 월 부터 10 월 까지 4 개 월이 었다.

\section{고 찰}

능포 정치망 어장에서 가장 많이 어획된 어종 은 전 갱이로, 본 해역에 다량분포하는 어 종임 을 알 수 있었다. 다음으로 어획된 어종으로는 길 치, 멸치, 고등어, 청어, 살오징어 그리고 벤자리 등이며, 이들 어종들은 전갱이에 비하여 어획 량 은 많이 낮으나, 본지역에서 또한 중요한 무리를 형성하는 어종들이라고 생각된다. 기타 소량 혼 획된 어종들인 삼치(Scomberomorus niphonius),
대구(Gadus macrocephalus), 물메기(Liparis tessellatus), 아귀(Lophiomus setigerus), 연어 (Oncorhynchus keta), 말 쥐치(Thamnaconus modestus) 그리고 눈다랑어(Thunnus obesus) 등 은 일시적으로 어장에 어획된 어종들로 계절에 따라 이동성이 강한 회유성 어종들이다. 이 외 본 어장에서는 뱅에돔(Girella punctata), 한치오 징 어(Loligo chinesis), 잿방어(Seriola dumerili), 독가시치(Siganus fuscescens) 그리고 긴가라지 (Decapterus macrosoma) 등도 출현하였는데, 이 들 은 제주도 이남해역의 따뜻한 수역에 주로 찾 아볼 수 있는 온대난류성 어종들이다.

특히 본 조사에서 주 우점종인 전 갱이 어획량 은 $310,757.2 \mathrm{~kg}(57.5 \%)$ 으로 정치망에 서 차지하 는 어획비율이 높았다. 이는 다른 정치망 어장인 제주도 북촌에서 전갱이가 차지하는 비율인 42.4\%(Go and Shin, 1988), 화순 35.4\%(Go and Shin, 1990), 한림 69.2\%(Kim et al., 1999), 평 대 32.4\%(Cha et al., 2001), 구엄 70.2\%(Cha et al., 2001), 두모 0.1\%(Cha et al., 2001), 함덕 34.6\% (Cha et al., 2004), 귀 덕 22.2\%(Cha et al., 2008) 그 리고 남해안의 여수 연 안0.5-75.6\%(Kim, 1993; Kim et al., 1988, 1989; Kim and Rho, 1995, 1996) 그리고 경북 연 안인 12.2\%(Hong and Lee, 1995) 에 비하여 본 어 장에 서 전 갱이 가 차지하는 비율 이 높은 편에 속한다고 할 수 있다. 따라서 능포 정치망 어황을 이해하는 데는 전 갱이 어 획량 변 동원인을 먼저 퐈악하는 것이 중요한 요소 중의 하나가 될 수 있을 것으로 판단된다. 그런데 본 조사에서 전 갱이 어 획량이 많은 것은 능포 어장 을 포함한 거제도 주변해역에 전갱이 어군이 다 량 분포하고 있으며, 따라서 이들 어 군이 어 장으 로 유입되었기 때문이라 할 수 있다. 특히 거제 도 동부 연안은 쿠로시오의 지류인 대 마난류수 의 영향을 받는 곳이며, 수온이 연 중 $10^{\circ} \mathrm{C}$ 이상 을 유지하고 있어 전 갱이 어군이 분포하기에는 호조건 의 환경이라 생 각된 다.

하지만, 전 갱이 어군은 강한이 동적 성 향을 지 
니며, 따라서 시기에 따른 전갱이 어획량의 변화 폭은 매우크게 나타났다 전 갱이 월 어획량 변동 의 경우, 능포 어장의 어기 초인 2003년 과 2004 년 의 5 월 경에 는 어 획량이 낮았지 만 6 월 이후에 는 점차 증가하여 2004 년 9 월 의 경 우, $70,000 \mathrm{~kg}$ 이상까지 나타내었다. 이 러한 어획량 변동특성 과 관련하여 전체 정치 망 어획 량은 2003년이 $166,263.4 \mathrm{~kg}$ 그리고 2004 년이 $374,424.6 \mathrm{~kg}$ 으로 두 배 이상 증가하였다. 물론 2004년의 정치 망 어획 량에 는 전갱이 이외 갈치, 멸치, 고등어, 청어, 벤 자리 등의 여러 우점종들의 어획 량 또한 증가하 고, 일부 어종들이 어장에 더 많이 가입 하였으며 그리 고 2004년과는 달리 2003 년 9 월과 10 월에 는 태풍에 의한 일시적으로 조업이 중단된 것이 원 인이 될 수 있겠지만, 2004 년과 2003년의 뚜렷한 어획량 차이는 무엇보다 주 어종인 전갱이의 어 획량 증가에 따른 다고 볼 수 있을 것이다.

한편, 본 능포 정치망 어업의 어기동안 근해해 역 $(98,99,100$ 해 구)에서 대형선 망에 의 한 전 갱 이 어획량을 보면(NFRDI, 2003 - 2004), 2003년 이 303 톤 그리고 2004 년 이 1,183톤으로 2004년 이 2003 년 에 비하여 약 4 배 나 많았다. 특히 2004 년 9 월 과 12 월에는 월 어획량이 다른 월에 비하 여 크게 증가하여 각각 300 톤 이상, 400 톤 이상 으로 높았다. 여기서 근해 어획량이 증가하였다 는 것은 전 갱이 어 군의 분 포밀 도가 높아져 많은 개체들이 어획되었기 때문이며, 어획량이 감소 하였다는 것은 반대로 어군의 분포밀 도가 낮아 져 소량의 개체들이 어획되 었다고 볼 수 있을 것 이다. 따라서 2004년 의 많은 근해 전갱이 어획량 은 당시 전갱이 어군이 다량 분포하였기 때문이 며, 이러한 전 갱이 어 군의 일 부가 연 안으로 몰려 오면서 2004년의 정치망 전갱이 어획량도 증가 한 것으로 판단된 다. 이 시기의 근해에서 대형선 망에 어획된 전 갱이 어 군의 크기는 $20-30 \mathrm{~cm}$ 범 위로 본 정치망 어 장에서 어획되는 전갱이 어군 의 크기와 같았다. 그런데 Cha et. al.(2001)의 제 주도 구엄 연안의 정치망 조사에 의 하면, 정치망
전 갱이 어획량은 1999 년 10 월 에 $45,000 \mathrm{~kg}$ 이상 까지 급상승하였는데, 이는 같은 시기의 근해해 역에 분포하고 있던 전 갱이 어군이 다량으로 어 장에 가입하였기 때 문이라고 고찰한 바 있다. 따 라서 본 조사를 포함한 연안 정치망에는 근해 전 갱이 어획량이 정치망 어 황에 영향을 미치는 중 요한 요소라고 할 수 있을 것이다. 그러나 근해 해역에서 전 갱이 어 군의 분포량이 많아지는 것 은 자원량 자체가 늘어나서 인지, 아니면 일시적 으로 어군이 밀집하여 생 겨 나타난 현 상인지 별 도 조사가 진행되 어야 할 것으로 생 각된 다.

그려나, 근해 어장의 전 갱이 어획량과 정치망 어장의 전갱이 어획량과의 관계는 수온에 따라 또한 매우 다른 결 과를 보여 주었다. 즉, $17^{\circ} \mathrm{C}$ 이 상의 어장수온에서는 근해 전갱이 어획량이 많 으면 많을 수록 정치망의 전갱이 어획량도 많은 경향을 보 였지 만 $17^{\circ} \mathrm{C}$ 미 만의 수온에 서는 근해 전갱이 어획량과 정치망 전갱이 어획량 간에는 별 다른 관련성을 보이지 않았다. 오히려 근해 전 갱이 어획량이 430 톤 이 상이 라 하더라도 정 치망 에서의 전갱이 어획량은 1 톤 미만에 불과하였 다. 이러한 결과는 다음과 같이 요약할 수 있을 것이다. 난류성 어종인 전 갱이는 저수온일 때는 거제도 능포 어장의 외해측에 머무르지만, 수온 이 상승하게 되면 연안으로이동하여 정치망 어 장에 가입함으로서 정치망의 전갱이 어획량이 증가하게 된다고 볼 수 있을 것이다. 여기서 $17^{\circ}$ $\mathrm{C}$ 수온은 한국근해 전 갱이가남해 및 제주도 주 변에 머물러 있다가 황해 및 동해로 북상회유하 는 시기의 범위 내에 있는 어장 적수온과 같은 것이며, 따라서 본 조사에서는 근해 전 갱이 어획 량과 연안정치망 전 갱이 어획량과의 관계를 가 지게 하는 수온범위라고 볼 수 있다.

하지만, $17^{\circ} \mathrm{C}$ 이상을 나타내 는 어 장수온 기간 중에 정치 망에 어획된 전 갱이 어획량을 보면, 2003 년 이 82 톤, 2004 년이 202 톤으로 2004 년이 2003 년 에 비하여 2.5 배 많았다. 같은 기간 중의 근해 전 갱이 어 획량은 2003 년이 약 2 톤, 2004 년 
이 525 톤으로 2004 년 이 2003년에 비하여 260 배 이상 많았다. 고수온 $\left(17^{\circ} \mathrm{C}\right.$ 이상) 기간은 2003 년 이 6 월 부터 11 월 까지 6 개 월 정 도이 며, 2004년은 7 월부터 10 월까지 4 개월 정도이었다. 따라서 2004 년 이 2003년 에 비 하여 고수온 기간이 2 개 월 정도 짧았음에도 불구하고 정치망에서의 전갱 이 어획량은 2004년이 2003 년 에 비하여 오히려 많았다. 이것은 같은 기간에 정치망에 가입할 수 있는 조건인 근해 전 갱이 어 군의 2004 년 어획량 이 2003 년에 비하여 훨씬 많았기 때 문이라 할 수 있다. 따라서 이러한 결과는 정치망 전갱이 어획 량의 증가 및 감소가 수온에 의한 영향도 크지 만, 근해 전갱이 분포량과같은 생물학적 요인이 또한 중요한 환경요소가 될 수 있음을 보여주는 결 과라고 판단된 다. 결 과적으로 능포 정치망 어 황의 주 변동요인이 되는 전갱이 어황은 적절한 수온대의 형성 그리고 이와 함께하는 근해 전갱 이 어군의 분포밀도 등에 의해 크게 결정될 수 있을 것으로 사로된 다. 참고로 본 조사에서는 능 포 정치망 어황을 이해하는 데 있어서 주 우점종 인 전갱이 어획량과 어 장수온만으로 자료를 해 석하고자 하였다. 그러나 기타 환경요인인 염 분 의 변화, 지 형적인 특성, 해류의 이동, 태풍의 영 향, 기 후변화, 포식자의 존재유무 그리고 적조발 생 등도 함께 시기적으로 고려하여 적용한다면 보다 세 밀한 측면에서 어획량의 증가 및 감소를 분석하고이해할 수 있을 것으로 판단된다.

\section{결 론}

거제도 능포 정치 망 어장에 서 2003 년부터 2004 년까지 2 개년 동안 어획된 어획물의 총 어 획 량은 $540,688.0 \mathrm{~kg}$ 그리고 어획된 어 종은 총 48 어종이었다. 전 갱이 가 $310,757.2 \mathrm{~kg}$ 으로 전체의 $57.5 \%$ 를 차지하여 가장 많이 어획되었다. 다음 으로 갈치(12.9\%), 멸치(10.6\%), 고등어(6.9\%), 청어(4.5\%), 살오징 어(2.8\%) 그리고 벤자리 (1.3\%) 등의 순이었으며, 그 외 어 종들은 소량어 획되었다. 계절별 출현 어종들로는 청어, 멸치,
대 구, 물메기, 아귀, 연어, 말쥐치 그리고 눈다랑 어 등이었다.

연 도별 어획량은 2003 년이 $166,263.4 \mathrm{~kg}$ 그리 고 2004년 이 $374,424.6 \mathrm{~kg}$ 이 며, 어 획종수는 2003 년이 32 어종, 2004 년이 38 어종으로 2004 년이 2003년에 비하여 어획량과 어종수에서 많았다. 이것은 2004 년이 2003 년보다 전갱이, 갈치, 멸 치, 고등어, 청어, 벤자리 등의 우점종들의 어획 량이 증가하였기 때문이며, 주 원인은 전갱이의 어획량이 크게 증가하었기 때문이다. 그러므로 본 조사 결과, 거제도 능포 연안의 정치망 어장 에 는 눈 다랑어와 같은아열대 성 어종과 청어, 연 어, 대구 등과같은 한대성 어종, 그리고 전갱이, 갈치, 멸치, 삼치 등과 같은 온대난류성종 등이 고루 분포하고 있으며, 어획량은 전 갱이 와 같은 회유성 어종에 의해 큰 영항을 받고 있는 것으로 나타났다.

\section{사 사}

본 논문은 국립수산과학원 경상과제인 '연안 수산 자원조성 기 반연 구' 사업의 연 구항목인 서 식 생 물조사 (과학원 간행 물 등록번호, RP 2009 -RE -015)에 의 거 수행되었으며, 조사에 협조하여 주신 거제도 능포 정치망 어장의 어업 인 에게 고마움을 전 합니 다

\section{참고문헌}

Cha, B.Y., B.Y. Kim and S.W. Oh, 2001. Catch variation and fishing period of the set net fishery in coastal waters of Jeju Island. Kor. J. Ichthyol., 13(3), 210 219.

Cha, B.Y., D.K. Kim and S.H. Seo, 2007. Species and abundance of fish by a gill net in coastal waters of Sounthern Sea, Korea, 2006. Kor. J. Ichthyol., 19(3), $210-224$

Cha, B.Y., D.K. Kim, J.T. Yoon and B.Y. Kim, 2008. Composition and catch variation of fishes by a set net in the coastal waters off Gwideuk, Jeju Island. Kor. J. Ichthyol., 20(1), 28 - 35. 
Cha, B.Y., D.S. Chang and B.Y. Kim, 2004. Seasonal variation of fish catch by a set net in Hamdeuk fishing ground off Jeju Island. J. Kor. Fish. Soc., 37(1), $65-72$.

Go, Y.B. and H.S. Shin, 1988. Species occurrence and food chain of fisheries resources, nekton, on the coast of Pukchon, Cheju Island. I. Species composition and diversity. Bull. Kor. Fish Soc., 21(3), $131-138$.

Go, Y.B. and H.S. Shin, 1990. Species composition and diversity of fisheries resources, nekton, off the coast of Hwasun, Southern part of Cheju Island. Kor. J. Ichthyol., 2(1), 36 - 46.

Han, K.H., J.H. Kim and S.R. Baek, 2002. Seasonal variation of species composition of fishes collected by set net in coastal waters of Ulsan, Korea. Kor. J. Ichthyol., 14(1), $61-69$.

Hong, J.P. and J.H. Lee, 1995. The fluctuations of catches in set nets around Kyeongbuk Province. Bull. Kor. Soc. Fish. Tech., 31(2), 153 - 165.

Hwang, S.D., J.Y. Kim, J.I. Kim, S.T. Kim, Y.I. Seo, J.B. Kim, Y.H. Kim and S.J. Heo, 2006. Species composition using the daily catch data of a set net in the coastl waters off Yeosu, Korea. Korean J. Ichthyol., 18(3), 223 -233.

Kim, D.S, 1993. Environmental factors and catch fluctuation of set net grounds in the coastal waters of Yeosu. Bull. Kor. Soc. Fish. Tech., 29(2), 94 -108.

Kim, D.S. and H.K. Rho, 1995. Environmental factors and catch fluctuation of set net grounds in the coastal waters of Yeosu. 3. The quantity of phytoplankton and catch fluctuation. Bull. Kor. Soc. Fish. Tech., 31(1), $15-23$.

Kim, D.S. and H.K. Rho, 1996. Environmental factors and catch fluctuation of set net grounds in the coastal waters of Yeosu. 4. Water temperature and salinity and fluctuation of catch. Bull. Kor. Soc. Fish. Tech., 32(2), 125 - 131.

Kim, D.S., C.C. Lee and Y.S. Park, 1988. Oceanographic condition and fishing condition of the set net fishing ground in Yeosu Bay. Bull. Kor. Soc. Fish. Tech., 24(4), $150-157$.

Kim, D.S., C.C. Lee, D.A. Kim and Y.S. Park, 1989. The characteristics of a fishing ground at Yeosu Bay. pound net fishing ground. Bull. Kor. Soc. Fish. Tech., 25(2), $44-53$.

Kim, J.T., D.G. Jeong and H.K. Rho, 1999. Environmental character and catch fluctuation of set net ground in the coastal water Hanlim in Cheju Island. J. Kor. Fish. Soc., 32(1), 105 -111.

Kim, Y.H., J.B. Kim and D.S. Chang, 2003. Seasonal variation of abundance and species composition of fishes caught by a set net in the coastal waters off Yosu, Korea. J. Kor. Fish. Soc., 36(2), 120 - 128.

NFRDI(National Fisheries Research \& Development Institute), 2003 - 2004. Reports of catch data by Large purse seine fishery(unpublished book), pp. 369.

2009년 8월 6일 접수

2009년 9월 28 일 1차 수정

2009 년 10 월 25 일 2 차 수정

2009년 10월 27 일 수리 
Appendix 1. Species composition and abundance of fisheries resources caught by a set net in the coastal waters off Neungpo, Goeje Island, 2003

\begin{tabular}{|c|c|c|c|c|c|c|c|c|c|c|}
\hline Species & Apr. & May & Jun. & Jul. & Aug. & Sep. & Oct. & Nov. & Dec. & Total \\
\hline Acanthopagrus schlegeli & & & & 1.3 & & & & & & 1.3 \\
\hline Channa argus & & & & & & 1.2 & & & & 1.2 \\
\hline Clupea pallasii & & & & & & & & & $6,090.2$ & $6,090.2$ \\
\hline Engrdaulis japonicus & $3,165.7$ & $2,475.3$ & $1,440.8$ & $1,320.7$ & & & & 135.6 & $19,955.4$ & $28,493.5$ \\
\hline Gadus macrocephalus & & & & & & & & 13.1 & 21.5 & 34.6 \\
\hline Konosirus punctatus & 348.2 & & & & & & & & & 348.2 \\
\hline Lateolabrax japonicus & 13.2 & & & & & & & 3.3 & 1.4 & 17.9 \\
\hline Liparis tessellatus & & & & & & & 78.5 & $1,116.3$ & 672.9 & $1,867.7$ \\
\hline Loligo chinesis & & & & & & & 3.6 & 50.8 & & 54.4 \\
\hline Lophiomus setigerus & 162.3 & 55.1 & & & & & 2.2 & 179.3 & 547.2 & 946.1 \\
\hline Pagrus major & 1.3 & 3.2 & & & & & & 5.4 & & 9.9 \\
\hline Pampus argenteus & & 3.8 & 5.2 & & 982.3 & 90.9 & & 27.2 & 5.3 & $1,114.7$ \\
\hline Paralichthys olivaceus & & & & & & & & 1.7 & & 1.7 \\
\hline Paroctopus dofleini & & & & & & & & & 2.1 & 2.1 \\
\hline Platycephalus indicus & & & & 36.4 & 1.1 & & & & & 37.5 \\
\hline Pleronichthys cornutus & & & & & & & & 4.3 & 13.1 & 17.4 \\
\hline Psenopsis anomala & & & & & & 795.2 & 45.8 & & & 841.0 \\
\hline Sardinella zunasi & 540.7 & 539.6 & & & & & 75.4 & & & $1,155.7$ \\
\hline Scomber japonicus & & & 45.3 & & & & & & & 45.3 \\
\hline Scomberomorus niphonius & & 494.5 & 355.6 & 2.2 & 81.6 & 24.4 & 58.1 & 50.6 & 15.7 & $1,082.7$ \\
\hline Sebastes schlegeli & 6.1 & 4.2 & & & & & & & & 10.3 \\
\hline Semicossyphus reticulatus & & & & & & & 30.2 & 54.1 & 4.2 & 88.5 \\
\hline Seriola lalandi & 107.3 & 118.7 & 4.3 & & & & & & & 230.3 \\
\hline Seriola quinqueradiata & & & & & 136.5 & 12.7 & 3.8 & & & 153.0 \\
\hline Siganus fuscescens & & & & & & & & 93.3 & & 93.3 \\
\hline Sphyraena pinguis & & & & & & & 75.2 & 150.6 & & 225.8 \\
\hline Tetraodontiformes & 11.0 & 35.2 & 37.7 & 1.6 & & & & 24.9 & & 110.4 \\
\hline Thamnaconus modestus & 10.5 & 13.2 & 2.8 & 1.5 & & & & 1.4 & 9.5 & 38.9 \\
\hline Thunnus obesus & & & & & 153.2 & & & & & 153.2 \\
\hline Todarodes pacificus & 296.5 & $9,875.2$ & $3,480.2$ & & & & & & & $13,651.9$ \\
\hline Trachurus japonicus & & 225.3 & $13,945.1$ & $21,360.1$ & $16,740.4$ & $9,750.4$ & $7,785.7$ & $12,630.7$ & $8,925.3$ & $91,363.0$ \\
\hline Trichiurus lepturus & & & 15.2 & $3,555.2$ & $10,170.3$ & $1,090.2$ & $1,080.3$ & 750.4 & $1,320.1$ & $17,981.7$ \\
\hline Total catch(kg) & $4,662.8$ & $13,843.3$ & $19,332.2$ & $26,279.0$ & $28,265.4$ & $11,765.0$ & $9,238.8$ & $15,293.0$ & $37,583.9$ & $166,263.4$ \\
\hline Number of species & 11 & 12 & 10 & 8 & 7 & 7 & 11 & 18 & 14 & 32 \\
\hline
\end{tabular}


Appendix 2. Species composition and abundance of fisheries resources caught by a set net in the coastal waters off Neungpo, Goeje Island, 2004

\begin{tabular}{|c|c|c|c|c|c|c|c|c|c|c|}
\hline Species & Apr. & May & Jun. & Jul. & Aug. & Sep. & Oct. & Nov. & Dec. & Total \\
\hline Aluterus monocerus & & & & & & 57.8 & 28.5 & 6.4 & & 92.7 \\
\hline Auxis rochei & & & & & & & & $2,600.4$ & & $2,600.4$ \\
\hline Canthigaster rivulatus & & & & & & & & 80.6 & & 80.6 \\
\hline Channa argus & & & & & & 3.5 & & & & 3.5 \\
\hline Clupea pallasii & $6,300.2$ & $2,000.6$ & $8,095.4$ & & & & & & $1,745.2$ & $18,141.4$ \\
\hline Decapterus macrosoma & & & 270.6 & $2,065.6$ & & & & & & $2,336.2$ \\
\hline Engrdaulis japonicus & 945.6 & $7,530.3$ & $19,085.9$ & 945.3 & 40.3 & & & & & $28,547.4$ \\
\hline Gadus macrocephalus & 3.1 & & & & & & & 2.0 & 35.3 & 40.4 \\
\hline Girella punctata & & & & & & & & 20.4 & 87.8 & 108.2 \\
\hline Gymnothorax kidako & & & & & & & & 151.5 & 494.9 & 646.4 \\
\hline Isurus oxyrinchus & & & 90.2 & & & & & & & 90.2 \\
\hline Liparis tessellatus & 55.2 & & & & & & 16.3 & 77.5 & 10.2 & 159.2 \\
\hline Loligo chinesis & & & & & & & 43.2 & & & 43.2 \\
\hline Lophiomus setigerus & 448.2 & 83.4 & 5.1 & & & & & 3.1 & 178.3 & 718.1 \\
\hline Mola mola & & & & & & & & 80.4 & & 80.4 \\
\hline Mugil cephalus & & & & & & & & & 107.9 & 107.9 \\
\hline Oncorhynchus keta & & & & & & & 2.7 & & & 2.7 \\
\hline Oplegnathus fasciatus & & & 1.4 & & & & 34.2 & 33.0 & & 68.6 \\
\hline Pagrus major & & & & & 1.5 & & & & & 1.5 \\
\hline Parapristipoma trilineaturm & & & & & & & & $7,050.6$ & & $7,050.6$ \\
\hline Pleronichthys cornutus & 10.2 & & & & & & & & 4.5 & 14.7 \\
\hline Psenopsis anomala & & & & & 90.6 & 40.9 & 60.4 & & & 191.9 \\
\hline Scomber japonicus & & & & & & $16,675.1$ & $20,410.6$ & 30.7 & & $37,116.4$ \\
\hline Scomberomorus niphonius & & 103.7 & 112.5 & & 18.7 & 879.2 & 985.6 & 143.3 & 223.3 & $2,466.3$ \\
\hline Sebastes schlegeli & & 2.7 & & & & & & & & 2.7 \\
\hline Semicossyphus reticulatus & 23.2 & & & & & & 150.6 & 127.7 & & 301.5 \\
\hline Sepiolidae & 326.1 & 50.2 & & & & & & & & 376.3 \\
\hline Seriola dumerili & & & & & 260.5 & 96.4 & 6.5 & & & 363.4 \\
\hline Seriola lalandi & & 262.2 & 9.3 & & & & & & & 271.5 \\
\hline Siganus fuscescens & & 10.4 & 32.3 & 21.4 & 2.1 & & & & & 66.2 \\
\hline Speia esculenta & & 5.3 & & & & & & & & 5.3 \\
\hline Sphyraena pinguis & & & & & & & 15.7 & & & 15.7 \\
\hline Takifugu chinensis & & 10.1 & 7.5 & & & & & & & 17.6 \\
\hline Tetraodontiformes & & & & & & & & & 1.5 & 1.5 \\
\hline Thamnaconus modestus & 4.2 & 10.6 & 1.2 & & & & & & 3.5 & 19.5 \\
\hline Todarodes pacificus & & 575.3 & 791.7 & & & & & & & $1,367.0$ \\
\hline Trachurus japonicus & 120.3 & $1,970.4$ & $15,110.6$ & $58,435.6$ & $29,940.2$ & $71,160.3$ & $42,075.8$ & 40.5 & 540.5 & $219,394.2$ \\
\hline Trichiurus lepturus & 180.2 & & $3,210.4$ & 45.3 & $1,500.5$ & $1,315.6$ & $11,720.4$ & $22,715.3$ & $10,825.6$ & $51,513.3$ \\
\hline Total catch(kg) & $8,416.5$ & $12,615.2$ & $46,824.1$ & $61,513.2$ & $31,854.4$ & $90,228.8$ & $75,550.5$ & $33,163.4$ & $14,258.5$ & $374,424.6$ \\
\hline Number of species & 11 & 13 & 14 & 5 & 8 & 8 & 13 & 16 & 13 & 38 \\
\hline
\end{tabular}

